\title{
IS THE COSMOS FINE-TUNED FOR LIFE, OR FOR THE POSSIBILITY OF LIFE? (AND WHY PATRISTIC AND MEDIEVAL DEMONOLOGY MIGHT HOLD PART OF THE ANSWER)
}

\author{
Travis Dumsday
}

\begin{abstract}
Contemporary physics and cosmology have accumulated a great deal of empirical evidence for the claim that in order for our universe to contain life, an array of incredibly precise laws, constants, and specific initial conditions had to be in place. The minuscule odds of this happening purely by chance have prompted some Christian thinkers to suggest that this can be seen as novel evidence that the universe was fine-tuned specifically to give rise to biological life. And yet some Christian thinkers also wish to make the case that molecular biology provides new evidence to the effect that life could not have arisen naturally in our universe, but rather that the origin of life required additional special divine intervention. There is at least a prima facie tension between these two ideas. Relatedly, some have raised the question of why, if the universe were fine-tuned for life, it was also set up in such a way that the origin of life was preceded by more than 10 billion years of lifelessness. If life was the whole point, why the seeming delay? In this paper I suggest a way Christian thinkers might address both issues: namely, the cosmos was not fine-tuned for life, but merely for the possibility of life. Perhaps God wanted a universe in which biological organisms were possible (including intelligent organisms like us) but in which their non-existence was also a live possibility. I develop this solution in dialogue with related ideas arising from the demonologies of St. Augustine, Boethius, and St. Anselm.
\end{abstract}

\section{Introduction}

The philosophical and theological literature on alleged cosmic fine-tuning is substantial. ${ }^{1}$ The basic empirical claim is that contemporary physics and cosmology have provided good evidence to the effect that in order for

\footnotetext{
${ }^{1}$ See for instance Barr, Modern Physics; Collins, "The Teleological Argument"; Koperski, The Physics of Theism, ch. 2; Lennox, God's Undertaker, ch. 4; Leslie, Universes; McGrath, A Fine-Tuned Universe; Ross, Why the Universe Is the Way It Is; and Swinburne, The Existence of God, ch. 8.
} 
biological life to exist in our universe, a whole array of incredibly precise laws, constants, and initial conditions had to be in place. The inference drawn from this is that such precision is unlikely to have been the product of mere random chance, so that the probability of the cosmos being intelligently designed for life is high. Oftentimes this is developed further into a piece of natural theology, an argument for theism aimed at persuading non-theists; at other times the evidence for fine-tuning is laid out simply as an item for in-house reflection amongst Christians, to employ as part of our discussions of divine providence in relation to physical nature. (For reasons that will soon become clear, in what follows our focus will be on fine-tuning considered within this latter context.)

There is also a substantial literature on alleged biological design, with the more recent entries in this literature being particularly focused on the idea that contemporary molecular biology has provided novel evidence to the effect that biological life could not have arisen naturally in our universe, but required separate intervention by an intelligent (perhaps supernatural) agent. ${ }^{2}$ Once again, this evidence is often presented as part of an argument for theism, though it too can likewise be put forward more as a topic for discussion amongst Christians regarding the nature, modes, and purpose of special divine action in the cosmos. E.g., one might pursue this line of inquiry simply from the perspective of whether it makes more sense theologically to suppose that biological life was fully "front-loaded" into the universe at the big bang (such that life was bound to arise naturally after that), or whether God wished to intervene specially to create life afterwards.

These two distinct lines of evidence for fine-tuning/design can of course be pursued independently, such that one can be accepted and the other rejected. (In fact, it is not uncommon for Christian thinkers to advocate for cosmic fine-tuning while staunchly rejecting the notion that there was later divine intervention to bring about biological life. For instance, Lamoureux, in his recent book Evolution: Scripture and Nature Say Yes, provides a clear defence of this stance.) Christian thinkers might also reject both, with neither rejection necessarily impacting their larger theological system or preferred scriptural interpretations. But can both lines of evidence be $a c-$ cepted as indicative of genuine fine-tuning or intelligent design? Or is there a tension, perhaps even incompatibility, between them?

Dougherty and Poston argue that there is at least a serious tension between those who wish to use cosmic fine-tuning as evidence for theism and/ or for a certain understanding of divine providence, and those who wish to invoke biological intelligent design along the same lines. Their development of the idea is detailed and sophisticated, and framed in terms of Bayesian probability theory. Still, the basic point can be simply stated:

\footnotetext{
${ }^{2}$ See for instance Axe, Undeniable; Behe, Darwin's Black Box; The Edge of Evolution; Darwin Devolves; Dembski, Intelligent Design; Denton, Evolution; Lennox, God's Undertaker, chs. 6-11; and Meyer, Signature in the Cell.
} 
In rough outline, the fine-tuning argument proceeds as follows: the a priori probability that the initial conditions of the universe and the values of the constants of the fundamental laws take their actual values is incredibly low. ... So the fact that the initial conditions and the constants of the fundamental laws have such and such actual values provides evidence for theism. The biological-design argument proceeds as follows (again in rough outline): it's incredibly unlikely that biologically complex organisms would exist somewhere or other in our universe. How unlikely? If we are to infer divine action from the existence of biologically complex organisms it must be nothing short of miraculous. That is 'statistical impossibility'. But note that if life is statistically impossible given the initial conditions of the universe, then there is very little sense to the notion that the universe is fine-tuned for life. True, there is some sense in which life is possible in such a universe, for God might specially create a micro-environment suitable for life. But that's true of any set of initial conditions. ${ }^{3}$

In other words, those advocating cosmic fine-tuning rely on the idea that the designer of the cosmos wanted it to contain life and so laid out its constants and initial conditions with that end in mind; and according to some, the designer wanted not merely to permit life, but to structure the cosmos in such a way that life would eventually arise naturally within it. Dougherty and Poston ${ }^{4}$ quote Swinburne as a prominent proponent of this interpretation of fine-tuning, with the latter writing that there "will be an argument from the existence of human (and animal) bodies to the existence of God of any great strength, via the route of 'fine-tuning', only if it follows that a fine-tuned universe will (not merely possibly but with significant probability) lead to embodied humans and animals." ${ }^{5}$ The implication there is that a fine-tuned universe is designed for life precisely in the sense that it will of itself be naturally disposed to give rise to biological organisms. By contrast, those advocating the teleological argument from biological intelligent design rely on the idea that life could not have arisen naturally in the cosmos, and instead must have been the result of a new and distinctive special intervention by a designer long after the big bang. But the second teleological argument seems to conflict with the first, since if life could not have arisen naturally in the cosmos then it seems less likely that the cosmos was actually designed with life as the specific end in mind.

Naturally there are potential replies to this argument, some of which are taken up by Dougherty and Poston. One that is particularly relevant for our purposes is as follows:

It might be objected by the apologist who wishes to hold on to both the FTA [fine-tuning argument] and the BDA [biological design argument] that God might find it more valuable to first create a world which allowed for, but probabilistically precluded, life and then add life in as a 'fingerprint'. To this

${ }^{3}$ Dougherty and Poston, "A User's Guide," 100.

${ }^{4}$ Dougherty and Poston, "A User's Guide," 103.

${ }^{5}$ Swinburne, The Existence of God, 189. 
we have three replies. First, either the FTA or the BDA by themselves would count as such a 'fingerprint.' Secondly, it would take independent argument that this was a better state of affairs than a single-stage creation as the strong FTA advocate alleges; it is not enough to merely assert that it is. Finally, notice that all the work in such a two-stage approach is being done by the BDA data, the 'fine-tuning' data simply serve as a backdrop to make biological design stand out. Thus this approach is not a reply to our criticisms but rather a capitulation and a choice of the BDA over the FTA. ${ }^{6}$

So they reject the suggestion that the FTA be re-conceived in such a way that the designer's proximate intention be understood not as an intention to design for life, but merely for the possibility of life. They reject it in large part because the apologist's suggestion is that God did this in order to showcase more clearly for us the fact of His particular care for the design of life-to reveal to us that life is the product of His special intervention. Dougherty and Poston dismiss as implausible this "revelatory strategy" approach to reconciling the FTA with the BDA. We thus have a problem before us: is there a way to understand God's providential plan for physical nature such that the FTA and the BDA are rendered clearly compatible?

Another, not unrelated question that can be raised with respect to alleged fine-tuning is this: if God intended the physical cosmos to give rise to life (whether of its own accord or with the later assistance of additional divine intervention), why is the cosmos set up in such a way that it took at least 10 billion years for life to arise? What theological sense can we make of this seeming delay in the origin of life? Or in other words: how are we to understand this aspect of God's providential plan? After all, if life is an intrinsic good, and in particular if the prospect of life is supposed to be motivating cosmic fine-tuning, why leave the universe devoid of it for eons? (As with the FTA/BDA consistency issue, this delayed life issue can be presented as a problem for natural theology in the context of the dialogue with atheism, ${ }^{7}$ or as an in-house question for Christian philosophers and theologians trying to get a clearer understanding of God's providential purposes for our universe. Our focus will again be on this latter, in-house angle.)

So we have two problems before us: (a) the problem of rendering compatible the FTA and the BDA, and (b) the question of how to understand what might have motivated the extended delay in the origin of life in a cosmos allegedly fine-tuned for life. While replies to these problems can of course be pursued independently of each other, it would be nice if there were some way of killing these two birds with one stone; it would be nicer if the core ideas employed in that single solution were also demonstrably non-ad hoc, perhaps already having an established place in historical theology; and it would be nicer still if that single solution drew on widely

${ }^{6}$ Dougherty and Poston, "A User's Guide," 105.

${ }^{7}$ For an entry point into that side of the delayed life issue see Dumsday, "Does a Delayed Origin for Biological Life Count as Evidence Against the Existence of God?" 
accepted, uncontroversial ideas within the Christian tradition, commonly maintained across denominations and within both modernist and traditionalist theological circles. As we'll soon see, the solution I will suggest meets the first two desiderata, but most assuredly does not meet the third. In fact, it violates the third with reckless abandon. That will disqualify it for some. Still, it may be worth exploring anyway.

The remainder of the paper is divided as follows: in the next section we take a detour into patristic and medieval demonology, examining St. Augustine's claim that humanity was created as a replacement for fallen angels. This idea was later taken up by Boethius and St. Anselm, after which it was largely abandoned in western theology. This may initially seem like rather a wide detour; but as we'll see, it is a necessary precursor to §3, where I suggest a way of modifying St. Augustine's idea in such a way that it is rendered somewhat less theologically problematic, and also able to address both the delayed life issue and the tension between the FTA and BDA. Finally, in $\S 4$ some potential objections are considered.

I should emphasize again: the FTA and the BDA have multiple potential applications within philosophy and theology. As already noted, some discuss one or another of these lines of evidence in the course of arguing for the truth of theism against non-theists, others simply by way of pursuing a deeper understanding of divine providence. This paper is concerned solely with the FTA and the BDA from the latter angle; the reason for this narrowed focus is that if one were instead trying to show the compatibility of the FTA and BDA as part of a strategy for ensuring their joint workability as arguments against atheism, reference to medieval angelology and demonology would likely render one's point worse than useless in that particular dialectical context. Much the same can be said regarding the delayed life issue: it can be broached as part of the atheism vs. theism dialectic or as an in-house topic for Christians interested in examining the possible providential reasons behind the timing of life's appearance, but if angels are being brought into the discussion then prudence dictates it should probably be restricted to the latter. ${ }^{8}$ If one is addressing a specifically Christian audience (and more specifically a traditionalist Christian audience that already accepts the reality of angels and demons), then there is at least a non-negligible chance of encountering some openness to the present proposal.

\section{Patristic and Medieval Theologians on Humanity as a Replacement for Fallen Angels}

The notion that God may have created humanity not for its own sake (or at least not primarily for its own sake), but with some other providential goal in mind, is one with a long history in Christian thought. Among the alternative providential goals that has been suggested is the following:

\footnotetext{
${ }^{8}$ Though I suppose one never knows: perhaps there are some secularists with a soft spot for angels!
} 
God created human beings to fill up the spots in the heavenly kingdom left vacant by fallen angels. Thus, God initially set out to create rational free beings, namely the angels. God hoped that the angels would choose eternal communion with Him in the kingdom of heaven, and furthermore He had a particular number in mind (i.e., God's creating $x$ number of angels was not a purely arbitrary decision-He had purposefully settled on a certain number to fill the heavenly host). However, some of those angels turned away from Him, thereby constituting themselves as demons. This left gaps in the desired number within the kingdom of heaven. God chose to fill those gaps by creating additional rational free beings, but rather than creating new angels He opted to create a different kind of entity, a being whose nature would be a mixture of rational and animal and who would be capable of sexual reproduction; so rather than God Himself having to create a massive number of new humans to fill the gap left by fallen angels, He had only to create two, male and female, graciously leaving in their hands the task of cooperating with His plan by producing new humans, whose subsequent descendants would eventually be sufficiently numerous to replace the fallen angels (and perhaps even to exceed that original number). But of course this second plan also did not quite work out as intended, since Adam and Eve fell too. God mercifully persisted in His intention to have humans fill the place of fallen angels, but now in order for them to fulfill that role they first had to be redeemed by His Son.

That is the basic outline of the replacement thesis, which finds its beginnings in St. Augustine and is later picked up by other patristic and medieval theologians. Novotny, in his book Cur Homo? A History of the Thesis Concerning Man as a Replacement for Fallen Angels, has produced a concise history of its role within Christian thought, and my summary above and in the remainder of this section is indebted to his work both in identifying relevant texts and interpreting the idea. The scope of my discussion will however be much narrower, focusing only on a select few figures.

The general idea comes up in several of St. Augustine's works, including one of his sermons: "In the heavens, you see, there is no being born or dying, from the moment when everything there was established. The chief of all the angels could indeed fall from there, together with his companions; but instead of those angels who fell, human beings are going to come there, and fill up the place of those who fell." ${ }^{\prime 9}$ The basic notion appears in other Augustinian texts, including Enchiridion 29:

And so it pleased God, the Creator and Governor of the universe, that, since the whole body of the angels had not fallen into rebellion, the part of them which had fallen should remain in perdition eternally, and that the other part, which had in the rebellion remained steadfastly loyal, should rejoice in the sure and certain knowledge of their eternal happiness; but that, on the other hand, mankind, who constituted the remainder of the intelligent creation, having perished without exception under sin, both original and

${ }^{9}$ The citation is from St. Augustine's Sermo 229/H,2, found in Hill, 296. 
actual, and the consequent punishments, should be in part restored, and should fill up the gap which the rebellion and fall of the devils had left in the company of the angels. For this is the promise to the saints, that at the resurrection they shall be equal to the angels of God. And thus the Jerusalem which is above, which is the mother of us all, the city of God, shall not be spoiled of any of the number of her citizens, shall perhaps reign over even a more abundant population.

\section{Consider finally the following, from City of God:}

Now God inflicted on the apostate angels, for their self-chosen fall, the just punishment of everlasting misery.... And God made man also upright, with the same power of free choice, an animal of earth, yet worthy of heaven if he adhered to the author of his being, but, by the same token, destined, if he abandoned God, for a misery appropriate to his kind of nature. Now God foreknew that man would sin by breaking God's Law through his apostasy from God; and yet, as in the case of the angels, God did not deprive man of the power of free choice, foreseeing, at the same time, the good that he was to bring out of man's evil. ${ }^{10}$ For out of this mortal progeny, so rightly and justly condemned, God by his grace is gathering a people so great that from them he may fill the place of the fallen angels and restore their number. And thus that beloved Heavenly City will not be deprived of its full number of citizens; it may perhaps rejoice in a still more abundant population. ${ }^{11}$

Another early Christian author who takes up the replacement theme is Boethius, in an early portion of his short work On the Catholic Faith:

But although in heaven all things are beautiful and arranged in due order, yet one part of the heavenly creation which is universally termed angelic, seeking more than nature and the Author of Nature had granted them, was cast forth from its heavenly habitation; and because the Creator did not wish the roll of the angels, that is of the heavenly city whose citizens the angels are, to be diminished, He formed man out of the earth and breathed into him the breath of life; He endowed him with reason, He adorned him with freedom of choice and established him in the joys of Paradise, making covenant aforehand that if he would remain without sin He would add him and his offspring to the angelic hosts; so that as the higher nature had fallen low through the curse of pride, the lower substance might ascend on high through the blessing of humility. But the father of envy, loath that man should climb to the place where he himself deserved not to remain, put temptation before him and the consort whom the Creator had brought forth out of his side for the continuance of the race, and laid them open to

\footnotetext{
${ }^{10}$ It is worth noting that although Augustine adopts a specific account of divine foreknowledge in relation to time (according to which God wholly transcends created temporal realms and so knows past, present, and future in an eternal/atemporal act of intellectual vision that from our temporal vantage point seems like foreknowledge), and although Boethius and Anselm adopt very similar understandings of God's relationship to time, I see no compelling reason why this would be essential to their shared commitment to the replacement thesis. I expect that open theists (for instance) could defend much the same idea, just paired with their own alternative account of divine temporality.

${ }^{11}$ Augustine, City of God, bk. 22, ch. 1, 1022-1023.
} 
punishment for disobedience, promising man also the gift of Godhead, the arrogant attempt to seize which had caused his own fall.

The replacement thesis, and variants of it, appear in other patristic figures and early medieval authors. Novotny points to St. Gregory the Great as proposing a version according to which God did not create man as a replacement, but $\mathrm{He}$ did save man in order to replace the fallen angels. ${ }^{12}$ Gregory thus shifts the focus of the idea from creation to salvation. But the original idea comes up again in multiple places within the works of St. Anselm, with one important locus of discussion being Cur Deus Homo. ${ }^{13}$ The treatment there is somewhat complex, and Anselm considers arguments for and against the replacement thesis, but Novotny maintains that Anselm's final position is in favour of it. ${ }^{14}$

The historical origins of the replacement thesis having now been reviewed, its potential relevance for our purposes can now be stated explicitly: supposing that thesis were true, and moreover that God had first created the physical universe and the angels (with the universe perhaps being intended as something the angels would have stewardship over) but had not yet created biological organisms (let alone humanity), then one could make some theological sense of the idea that the universe was designed not for life but for the possibility of life. God, foreseeing the possibility of an angelic fall and the potential need to replace the fallen angels with intelligent biological organisms, wanted a universe in which such organisms could be brought about if needed; but since such organisms would principally be a "backup plan" or corrective remedy, the universe would not be designed in such a way as to guarantee the occurrence of intelligent biological organisms (or indeed any biological organisms). ${ }^{15}$ Indeed it might have been designed in such a way as to allow for their natural survival should God choose to intervene and create them specially, but also designed in such a way that they could not arise naturally, in the absence of such special intervention. After all, on this hypothesis God wanted them on the scene only in the event that some of the angels fell.

Such a scenario, were it theologically acceptable, would serve to resolve the alleged tension between the FTA and the BDA, and would go some way towards explaining the delay in life's origin. It would address the latter by providing a non-ad hoc explanation as to why the universe was set up in such a way that life did not arise early in cosmic history; God

${ }^{12}$ Novotny, Cur Homo, 37.

${ }^{13}$ Anselm, Cur Deus Homo, bk. 1, chs. 17-23, 268-284.

${ }^{14}$ Novotny, Cur Homo, 58-59.

${ }^{15}$ The scare quotes around "backup plan" are intended to draw attention to the fact that depending on one's view regarding divine eternity vs. temporality (e.g., classical theism's atemporal God vs. one or another variety of open theism), one may or may not regard this as a literal indicator of putting a contingency plan in place for an unexpected outcome. Certainly Augustine's original idea was not intended to entail that God was faced with new-to-Him facts by either the angelic fall or by Adam's fall, even though Augustine clearly speaks of the relevant replacement as being in some sense a response to the angelic fall. 
had good reason to set the universe up in such a way that life would not arise naturally at all, let alone quickly. And perhaps the angelic fall did not take place until around the 11 billion year mark after the big bang, further explaining the delay in the start of the replacement process? Or perhaps the angelic fall happened early on in the history of the cosmos but God was content to wait quite a while to begin the replacement process? Or perhaps the sempiternal time in which the angels dwell is relevantly incommensurable (in whole or in part) with cosmic time, rendering tricky any attempted pairing of the two timescales? In any case, given the truth of the replacement thesis life's delay does receive an explanation, one whose central components have not been developed simply to solve the problem, but rather have longstanding roots in historical theology (thus showing it is not an ad hoc solution). With respect to the former problem, the tension between the FTA and the BDA is resolved insofar as cosmic fine-tuning is reinterpreted as fine-tuning not for life but merely for the possibility of life, which is entirely compatible with the claim that the actual occurrence of biological organisms requires further divine intervention.

That is not to say, however, that it would be entirely prudent to adopt the patristic/medieval replacement thesis wholesale and simply import it into the current debate over fine-tuning. Leaving aside (for now) concerns about bringing in literal talk of demons in order to address our two problems, later theological history should itself prompt caution. That history was in fact rather unkind to the replacement thesis, and after St. Anselm it is mostly opposed whenever it comes up for explicit discussion.

An early critic is Rupert of Deutz (circa 1075/1080-1129). Novotny relates how Rupert raises the question of why, if God had been so concerned to restore a particular number to the heavenly kingdom, He hadn't just created a massive swathe of new angels to fill the place of the fallen. ${ }^{16}$ Why bring humanity into the picture at all, if replacement was the only aim? ${ }^{17}$

\footnotetext{
${ }^{16}$ Novotny, Cur Homo, 76.

${ }^{17}$ In fairness it should be noted that Anselm had foreseen Rupert's worry, and attempted to address it:

And additional angels cannot take their place [i.e., the place of the fallen angels] because ... it would not be right for them to do so unless they could be such as the other angels would have been if they had not sinned. Now those original angels would have persevered without having seen God's vengeance upon sin; but once the original angels fell, that would be impossible for the additional angels who would be meant to take their place. For these two are not equally praiseworthy if they remain steadfast in the truth: one who has known no punishment for sin, and one who is always face to face with an eternal punishment. (Cur Deus Homo, bk. 1 , ch. 17, 268)
}

In other words, the newly created replacement angels would inevitably become aware of the prior fallen angels's damnation, such that their perseverance in virtue might then be motivationally inseparable from rational fear of punishment, and consequently less praiseworthy than those original angels who persevered simply from love of God. As such, the hypothetical angelic replacements, even if they persevered in virtue, would inevitably not be as good as the original angels who persevered, and so in the relevant sense would not really be (adequate) replacements. One worry (perhaps soluble?) facing this Anselmian reply would revolve around the question of whether it would have been possible and/or proper for God 
Novotny further summarizes Rupert's own preferred stance regarding the purpose of humanity's creation: "Man was not created for angels (that is, as a replacement for those who fell so that the number of those who persevered was completed); rather, the truth is that angels and all other creatures, including men, were created for man, meaning for Jesus Christ, the incarnate Word of God, through whom they are to become alike unto God, just as sons are like their fathers." ${ }^{18}$ This stance, and variants of it, becomes the standard view, being advocated by Honorius of Autun, Alain of Lille, Hugh of St. Victor, Peter Lombard, St. Albert the Great, St. Bonaventure, and St. Thomas Aquinas. The developing consensus was that God created humanity out of love for humanity, and a desire that it should share in God's own blessedness. Humanity was not created with the primary purpose of fulfilling a subordinate providential role, subordinate that is to some other order of being within creation (like the angels). Humanity was made for its own good, for the overarching good order and completion of the cosmos, and (relatedly) for the glory of God. Still, these authors are sometimes willing to admit some truth to the Augustinian position. For instance Hugh of St. Victor argues that although man was not created for the purpose of replacing the fallen angels, as a matter of fact man's salvation does have the happy side-effect of accomplishing that replacement, and Aquinas adopts the same view. ${ }^{19}$

So the replacement thesis was seen as problematic on at least two major fronts: (1) there was the problem of why, if fallen angels needed replacing (in order to maintain some divinely decreed minimum number of heavenly inhabitants) God didn't just create more angels, and keep creating them until a sufficient quantity refrained from rebellion that the desired number was reached. In other words, humanity might function as a replacement, but it is not clear why humanity specifically was introduced to fill that role. The replacement thesis as originally formulated seems therefore to be faced with an explanatory gap. (2) There seems something theologically problematic (and/or offensive?) to the suggestion that humanity's original primary purpose was to fill up a gap left by some other order within creation. While no one likes a jingoistic, unthinking anthropocentrism, this might seem to denigrate humanity's status. That denigration (if it is a denigration) would not merely offend our vanity, but also potentially conflict with the high status accorded us within scripture as objects of God's love and providential care.

Given the unhappy fate of the replacement thesis in later western theology, it would perhaps be unwise to place our bets on it as the basis of a reply to the delayed life argument and as a strategy for resolving the ten-

to bring new angels on the scene while also blocking their knowledge of past events in angelic history, including the fallen angels's desertion. This gets into deeper questions regarding Augustinian and Anselmian views on angelic epistemology.

${ }^{18}$ Novotny, Cur Homo, 82-83.

${ }^{19}$ See Novotny, Cur Homo, 119, 140. 
sion between the FTA and BDA or the delayed life question. Still, I think that a closely related idea might yet be able to do that work. This idea bears sufficient family resemblance to the replacement thesis that it too can plausibly avoid the charge of ad-hoccery, and correspondingly enjoy the advantage of having some precedent within historical theology. Yet it differs enough that it can also sidestep the more pressing theological objections facing the original replacement thesis. It does however still rely on acceptance of the literal reality of demons. That reliance will be a deal-breaker for many. But for readers who already believe in angels and demons (or at least are not wholly closed to the idea) the following suggestion may be worth considering.

\section{Replacing the Replacement Thesis}

In later western theology (most Scholastics after Peter Lombard), there arose a broad consensus that angels are purely spiritual entities, wholly incorporeal. ${ }^{20}$ That consensus has largely persisted, both in Catholic angelology and (to a considerable degree) Protestant angelology as well. However, that consensus was lacking in the patristic period, where a variety of perspectives on angelic corporeality existed; moreover, in contemporary Eastern Orthodox theology that patristic diversity has continued, with there being no official Church teaching on the issue. Yet even those fathers (including Augustine) who thought of angels as in some sense corporeal generally thought that their mode of corporeality was very different from that of human beings - the type of matter they were associated with was often thought of as very different, and certainly the angels were not thought of as biological organisms with the sorts of traits we associate with living things (metabolism and reproduction and vulnerability to natural death etc.). St. John of Damascus is not atypical when he writes that angels, in comparison with humans, are incorporeal since they lack bodily shape and spatial extension. ${ }^{21}$ Yet in comparison with God (who alone is wholly spiritual) they are very much embodied. Since demons were usually viewed as fallen angels, this conception carried over to them, although it was sometimes proposed that the bodies of demons were composed of a grosser/baser matter than that of unfallen angels. ${ }^{22}$

While cognizant of this historical diversity, in what follows I will assume for the sake of argument the post-medieval western consensus that angels and demons are wholly incorporeal. (The relevance of this will become apparent shortly.) With that assumption in mind let us return to one of the themes of the replacement thesis as laid out in the previous section:

\footnotetext{
${ }^{20}$ One might think that the advocacy of universal hylomorphism by figures like Bonaventure would contradict this point, but really it does not. The "prime matter" referenced in universal hylomorphism is not equivalent to the prime matter of Aquinas and other Scholastics, and is very far from what we would normally think of as "material."

${ }^{21}$ John of Damascus, On the Orthodox Faith, bk. 2, ch. 3, 205-207.

${ }^{22}$ For further background on the history of discussions surrounding angelic and demonic corporeality, see Keck, Angels, ch. 5, and Russell, Satan and Lucifer.
} 
God first created the physical cosmos and the angels. The timing of the angelic creation vis a vis the cosmos is not specified in scripture, but it has been widely (though not universally) held in both patristic and medieval theology that God either created the angels before the cosmos or not long after the cosmos; and it has been widely (though not universally) held that the creation of the angels preceded the creation of humanity.

Building on that, suppose an additional idea present in patristic theology, namely that God initially left the cosmos to the care and stewardship of the angels (or some subset of them). Further, at some point after this bestowal of stewardship, a large group of those angels rebelled against God, thereby constituting themselves as demons. Those fallen angels went on to wreak havoc on that cosmos, corrupting God's creation in a variety of ways. ${ }^{23}$ And suppose further that this is all long before humanity came on the scene, and perhaps also long before any biological life appeared in the cosmos. (Just what would corruption-of-creation have looked like, prior to the introduction of life and opportunities for inflicting pain and death on organisms? That is not clear; presumably it would have involved some sort of deliberate deviation from God's ordained structuring of the cosmos, but details here are difficult to fathom, and any attempt to flesh them out is liable to seem decidedly odd.)

Now suppose that God did not want to allow this corrupted state of affairs to continue indefinitely. There are of course a variety of ways in which He could have corrected the situation; for instance, He could have annihilated all of the fallen angels and then miraculously fixed whatever harm they might have done to the order of the cosmos. However, that would be seen by many as a theologically suspect strategy, insofar as historically most Christian thinkers have maintained that God never annihilates any of His rational creations, whether angelic or otherwise. (That historical fact helps to constitute one of the standard objections against annihilationist conceptions of hell.) So, another obvious option would have been to leave the demons in existence but remove from them any active ability to affect the cosmos, and then miraculously correct for any harm they might have done to it. However, that too is liable to sit poorly with traditional theological conceptions, according to which God is usually loath to rescind immediately a stewardship responsibility, upon that responsibility being abused. The consistent Biblical portrayal seems rather to be one in which the unfortunate consequences of sin are allowed to play out, at least for a time. (This is obviously connected to larger issues of theodicy, and why it is that God allows humans to persist in wrecking our own lives when He could supernaturally stop us.)

Now consider a third option: perhaps God could choose to correct the damage done to His creation "from the inside," as it were. That is, perhaps

${ }^{23}$ The notion that God initially gave angels stewardship over the physical universe, and that fallen angels took it upon themselves to corrupt that universe, is affirmed by a number of patristic authors. See for instance Athenagoras's A Plea for the Christians, chs. 10 and 24-25. 
God could choose to grant rationality and freedom to some component of the material cosmos, and grant to that spiritual/material hybrid the providential task of redeeming the cosmos, of wresting control of it from the fallen angels. How exactly this might work is obscure; but since the demons are (on the present hypothesis) wholly immaterial whereas these new beings would be partly spiritual and partly material, perhaps the latter's greater degree of intrinsic union with the basic stuff of the cosmos could in turn grant them a greater power over it, or at least the possibility of exercising such power by the grace of God. In other words, perhaps humanity came into an already-fallen cosmos with a high, noble, even heroic job to do: to take back that cosmos from the demons, restoring it to God's original intended order.

The idea that humanity came into the world with such a redemptive task already before it is of course not an original one. ${ }^{24}$ The twist I would like to add to it (inspired by the replacement thesis) is the following: perhaps the primary purpose of humanity was this redemptive mission, such that if the cosmos had not needed fixing (on account of abuse by fallen angels) it may be that God never would have created humanity, and perhaps never would have created any sort of biological life. Perhaps God's original plan for our reality was to have the physical cosmos and the angels, and that's it. However, foreseeing that some of the angels might fall, and in particular that some of the angels who had been granted stewardship over the cosmos might fall, God designed the cosmos in such a way that it had the ingredients of a "backup plan" already built-in: the cosmos was designed to allow for biological life just in case circumstances became so dire that God opted to institute the aforementioned redemptive plan. In other words, God designed the universe not for life but for the possibility of life, which possibility only He could realize through subsequent divine interventionintervention first to create biological life, and then subsequent intervention to ensure its evolution toward humanity.

If the present scenario were theologically palatable, it would have the virtue of singlehandedly resolving both the delayed life question and the FTA/BDA tension. It would accomplish the former by providing a non-ad hoc way of explaining why it is that God might have designed the cosmos in such a way that life was not naturally liable to arise, let alone arise quickly. This solution would be further assisted if one supposed that the angelic fall might have occurred relatively late in cosmic history, and/or that angelic time and cosmic time are not wholly commensurable, and/or that God had good reason for delaying the start of the redemptive project after the angelic fall had occurred. Regarding the last disjunct, such a delay would certainly accord with the aforementioned theological idea that God typically delays taking away an evil being's stewardship over its own domain - the idea of immediate or even quick correction of

${ }^{24}$ C. S. Lewis for instance nicely lays out the general idea in The Problem of Pain, 106-108, and in Miracles, 125-126. 
a being's sin does not accord with the Biblical portrayal of God generally allowing a being to exercise its freedom over an extended time, and of His allowing the effects of sin to become manifest. As to the FTA/BDA tension, the present proposal would dissolve it by providing a theological explanation for God's initially designing the cosmos not for life but for the possibility of life, and for why the subsequent occurrence of life would have required additional divine intervention.

So, the present scenario (for ease of reference, let's call it the redemption thesis) can solve both those problems. But then so could the replacement thesis; that thesis however arguably ran aground on two theological objections. Is the redemption thesis equally vulnerable to those two objections?

It is clearly immune from the first, which focused on the question of why God would opt to replace fallen angels with human souls when He could simply have replaced them with new angels. The redemption thesis is not proposing that humans are brought in to replace fallen angels, and so it does not encounter that problem. What of the second worry? It put forward the idea that the status of humanity would be denigrated by the supposition that our creation was not done for our own sake but rather to serve some task within a subordinate order of creation - namely, filling up slots in the heavenly kingdom left vacant by demons. Now, whether or not that objection holds with respect to the replacement thesis, I doubt that it holds for the redemption thesis; or at least I doubt that it holds with the same force. For on the redemption thesis, humanity actually has quite an exalted role to play in God's providential plan for His creation: we are to partner with Him in redeeming the cosmos. The idea that humanity might not have been part of His original intent for creation, but that we might instead have been brought in to correct a problem, need not be thought of as diminishing our status. Nor should it be thought of as undermining a recognition of God's love for us; after all, once we were brought into being we promptly failed in our redemptive task. Rather than justly destroying humanity, God opted instead to institute yet another redemptive plan, one that would involve His taking on our nature and dying for our sins. The redemption of the cosmos will still occur through humanity, but now it will occur through humanity as unified with God in Christ.

In fact, the incarnation provides something of a salutary analogy here. There has long been a debate within Christian theology about whether God became incarnate only in response to humanity's fall, or whether He would have taken on human nature even if we had never fallen. Both views are regarded as theologically orthodox, permissible positions, across denominational lines. Suppose now that the first view is true, and that the incarnation occurred in the context of a "backup plan," as a necessary corrective for humanity's sin that would not have been undertaken otherwise. ${ }^{25}$ Does that in any way diminish the glory of the incarnation

\footnotetext{
${ }^{25}$ Again, the "backup plan" language should not be taken as presupposing any particular account of God's foreknowledge or relationship to time.
} 
or the exalted status of Jesus Christ? Surely not. By the same token, if the very existence of humanity is a response to a previous angelic fall and the need to redeem the physical cosmos, the inherent value and glory of human nature is not thereby diminished.

Still, even if the redemption thesis sidesteps the particular problems facing the replacement thesis, it may be vulnerable to a host of other objections. In the final section we'll consider some representative examples.

\section{Objections and Replies}

(A) The redemption thesis still relies on the idea of literally real demons. This will render it unpalatable to many Christians, and wholly unworkable as a reply to actual atheists pressing the delayed life argument.

Granted, but as noted in the Introduction, the present discussion should be seen mainly as an in-house exercise amongst theologically traditional Christians who already buy into theologically traditional notions like literally real angels. And while there may be the odd atheist out there with a soft spot for the angelic, chances are that this fact will render the redemption thesis useless in addressing an atheist audience regarding issues of fine-tuning and the relationship between the FTA and BDA. But there is nothing wrong with seeing what internal resources the Christian tradition can provide for addressing such issues; likewise a Christian might be interested in the delayed life problem not because she fears being driven to atheism by it, ${ }^{26}$ but because the argument raises an intriguing theological question: if the universe is fine-tuned, why the delay in the origin of life? What was God up to in permitting this delay, or even actively intending it? And the redemption thesis is one option a Christian might consider when pondering the ways of God in light of modern cosmology and biology.

It is worth recalling as well that there are arguments available in favour of the literal reality of angels and demons: arguments from scripture, tradition, philosophical theology, ${ }^{27}$ and contemporary religious experience. ${ }^{28}$ The present proposal is certainly not alone in its strategy of looking to

\footnotetext{
${ }^{26}$ Though it certainly has been used as part of an argument for atheism - for an overview see again Dumsday, "Does a Delayed Origin."

${ }^{27}$ One might point for instance to Aquinas's well-known argument for the reality of angels on the basis of a principle of divine creative plenitude-see the Summa Theologica Ia, q. 50, art. 1. One might also point to the literature defending the possible relevance of demons in explaining so-called "natural" evil: see for instance Boyd, Satan and the Problem of Evil; Bulgakov, Bride; D'Arcy, The Pain of this World; Kelly, "The Problem of Evil and the Satan Hypothesis"; Mascall, Christian Theology; Pendergast, "Evil, Original Sin, and Evolution"; Plantinga, The Nature of Necessity and God, Freedom, and Evil; Trethowan, Essay; D. M. Webb, Why Does God Permit Evil?; and S. H. Webb, Dome of Eden.

${ }^{28} \mathrm{~A}$ surprisingly large range of sources might be cited here, but of particular interest is Heathcote-James, Seeing Angels. This work is a popularized version of her doctoral dissertation in cultural anthropology, which collected and analyzed hundreds of recent reported experiences of angels in the UK.
} 
traditional angelology and demonology as a potentially useful source for current theological reflection.

(B) Biological life is of such great intrinsic value, God must have intended it from the outset. It cannot have been a mere component in a "backup plan" for fixing a problem.

I sympathize with this objection, but I worry about the "must." It is worth recalling that the mere fact of something's being of great intrinsic value places God under no rational obligation to create it. There are for instance types of biological life that would presumably have been immensely valuable, which types God has opted not to instantiate in our cosmosunicorns and gryphons, for example. God is wholly free to create or not to create. His perfection (and by extension the perfection of Reality) would have been utterly undiminished if He had opted against creating anything at all. The creation of anything is an act of pure grace. Moreover, while biological life is intrinsically valuable, we typically tend to assign it an especially high intrinsic value because, as thoroughgoing moderns, we tend to assume uncritically the following proposition: finite rational agency requires biological life as a precondition. We humans are, after all, biological organisms, and we are the only rational agents we encounter in ordinary, everyday life, so it is natural enough to fall into that way of thinking. But of course Christian angelology instructs us to be wary of any such assumption; the good of finite rational agency can in fact be instantiated without there being any biological life, and on the present proposal that is precisely how our finite reality started out - with a physical cosmos and a host of free intelligent angels, but no biological life.

(C) All this talk of God having "backup plans" and whatnot is culpably anthropomorphic. God is outside of time, so the idea of God introducing new elements to a providential plan in light of sin (whether angelic or human) is just mistaken. If God intended to create humanity, that intention could not have been conditional on the occurrence of some unexpected state of affairs.

I am not suggesting that God was somehow taken unawares by the angelic fall, nor does the redemption thesis presuppose any particular, detailed account of the metaphysics of God's relationship to time. By analogy, those who think that God would not have become incarnate had it not been for Adam's sin do not thereby commit themselves to some naive view according to which this theological conditional in turn requires that God was somehow surprised by Adam's sin. How exactly the divine consciousness and divine will relate to time and contingency are, to put it mildly, contentious topics within Christian thought. Suffice it to say that nothing I have said in proposing the redemption thesis need provoke any new puzzles on this front, or any unique problems for classical theism versus open theism; moreover any such objection would apply just as 
much to the Augustinian replacement thesis, but as noted in section (2) above, there is no persuasive reason to think that that thesis cannot be understood in ways compatible with multiple different perspectives regarding God's relationship to time.

My own personal view on such matters is that God is atemporal but that this atemporality must somehow still be compatible with a real responsiveness to the contingencies involved in the actions of genuinely free created agents. How exactly to reconcile these two views is not easy, but that there must be a path to reconciliation follows from combined theological commitments to divine eternity and creaturely freedom. Lossky puts the point nicely:

With a certain excusable inexactitude, one could say that God in His providence condescends to the liberty of men. He acts as a result of this liberty, co-ordinating his actions with the acts of created beings, in order to govern the fallen universe by accomplishing His will without doing violence to the liberty of creatures. Therefore the mystery hidden before all ages in God and revealed to angels by the Church, ${ }^{29}$ this eternal and immutable foredetermination of the incarnation has at the same time a kind of contingency; one could almost say that it was occasional, provided this expression does not imply any idea of the unforeseen. ${ }^{30}$

(D) The redemption thesis seems enormously speculative. For instance, it was already admitted above that the details of what the demonic corruption of the cosmos (prior to the origin of life) might consist in are unclear. Moreover, the details of just how exactly humanity was to redeem the cosmos, to regain control of it from the fallen angels, have been left sketchy. How is one to evaluate a proposal which leaves so many questions unanswered?

Further details would be nice, if in fact one could find a way of plausibly fleshing them out. But I must admit that I find myself lacking in the imagination required to supply them. Perhaps for now, this task can be left as a topic for future research. I think the redemption thesis does supply at least a minimal core of content, content sufficient for evaluating whether it has a chance of being theologically workable and whether it can do the explanatory work here assigned it: namely, clearing up (at least for a Christian audience) the problems raised by the delayed life argument and Dougherty and Poston's observed tension between the FTA and the BDA.

(E) It has already been admitted that the redemption thesis is liable to be taken seriously (or semi-seriously) only by traditional Christians. Yet traditional Christians typically take their theological cues from the Bible and the historical mind of the Church, as manifested particularly by the early Church fathers and by later key theologians - for Catholics, the latter would include Scholastics like Aquinas,

\footnotetext{
${ }^{29}$ Here Lossky footnotes Ephesians 3:9-10.

${ }^{30}$ Lossky, Mystical Theology, 139.
} 
and for Protestants core figures like Luther, Calvin, and the Wesleys. With that in mind, the fact that the redemption thesis is nowhere to be found in the Bible or in these other sources of theological wisdom is surely a substantial blow against it. If humanity were created as part of a "backup plan," wouldn't God have revealed to us this rather important fact? Some arguments from silence do carry weight, and this seems like a good candidate.

Two points by way of reply: (1) the replacement thesis also had no explicit, unambiguous Biblical support, yet after its formulation by St. Augustine it received respectful attention from Christian thinkers for upwards of 800 years (though it was eventually rejected). Insofar as the redemption thesis borrows from and builds upon the replacement thesis, seeking to correct some of its long-recognized problems, perhaps it can borrow some of the latter's historical cachet? (2) Neither the Bible nor the historic tradition of the Church was explicitly faced with the cosmic fine-tuning and biological design data sets that we are faced with today. As such, there is nothing wrong in principle with raising new theological strategies for addressing new problems. By way of analogy, there is nothing wrong with coming up with novel strategies for attempting to reconcile Christian theology with the new data regarding the age of the universe and aspects of Darwinian evolution, despite the latter data sets having been unknown to the inspired authors of scripture and the early Church Fathers. ${ }^{31}$

(F) Surely there are other ways of addressing the delayed life problem and the alleged tension between the FTA and the BDA, ways that do not rely so heavily on controversial theological claims. With that in mind, the redemption thesis should be viewed as a last resort solution, one to be referenced only in the event that all other solutions to those two difficulties prove unworkable. Since we aren't there yet, there is not much point in discussing so far-out a proposal as this.

Certainly other strategies have been put forward for addressing the delayed life issue; much less has been written on the FTA/BDA conflict, but that is not to say it is irresolvable. (Perhaps, for instance, the "fingerprint of God" reply, considered and rejected by Dougherty and Poston and referenced in the Introduction above, is worthy of further discussion.) I am not suggesting the redemption thesis is the only workable solution to these two problems; however, it is one more option to put on the table, and perhaps not an unwelcome one given the current absence of generally agreed-upon resolutions. (It also has the virtue of explanatory range, providing a single resolution to both problems. As of yet there are no other proposals for killing these two birds with one stone.) Should it be viewed as a "last resort" option? That depends on one's background assumptions; if one is strongly inclined to disbelieve in the literal reality of angels and demons, and/or strongly inclined to think that humanity is the original, primary goal of cosmic fine-tuning, then indeed the redemption thesis

\footnotetext{
${ }^{31} \mathrm{My}$ thanks to an anonymous referee for supplying the latter reply.
} 
will plausibly be viewed as a last resort. If however one does not share those background assumptions, then it may be moved up, if not to the front row then perhaps somewhere in the middle-at any rate it needn't be relegated to the nosebleed section. ${ }^{32}$

\section{Concordia University of Edmonton}

\section{References}

Anselm. 2007. Cur Deus Homo. In Basic Writings, translated by Thomas Williams (Hackett), 237-326.

Athenagoras. 1885. A Plea for the Christians. Translated by B. P. Bratten (Christian Literature Publishing Co.). Available online at www.newadvent.org.

Augustine. 1887. Enchiridion. Translated by J. F. Shaw (Christian Literature Publishing Co.). Available online at www.newadvent.org.

Augustine.1993. Sermons 184-229Z. Translated by Edmund Hill (New City Press). Augustine. 2003. City of God. Translated by Henry Bettenson (Penguin).

Axe, Douglas. 2016. Undeniable: How Biology Confirms Our Intuition that Life is Designed (HarperCollins).

Barr, Stephen. 2003. Modern Physics and Ancient Faith (University of Notre Dame Press).

Behe, Michael. 1996. Darwin's Black Box: The Biochemical Challenge to Evolution (Simon \& Schuster).

Behe, Michael. 2007. The Edge of Evolution: The Search for the Limits of Darwinism (Simon \& Schuster).

Behe, Michael. 2019. Darwin Devolves: The New Science About DNA that Challenges Evolution (HarperCollins).

Boethius. On the Catholic Faith. Translated by H. F. Stewart and E. K. Rand. Available online at http://www.logoslibrary.org/boethius/catholic.html.

Boyd, Gregory. 2001. Satan and the Problem of Evil: Constructing a Trinitarian Warfare Theodicy (InterVarsity Press).

Bulgakov, Sergius. [1945] 2002. The Bride of the Lamb. Translated by Boris Jakim (Eerdmans).

Collins, Robin. 2009. “The Teleological Argument." In The Blackwell Companion to Natural Theology, edited by William Lane Craig and J. P. Moreland (Wiley-Blackwell), 202-281. https://doi.org/10.1002/9781444308334.ch4

D'Arcy, M. C. 1935. The Pain of this World and the Providence of God (Longmans).

Dembski, William. 1999. Intelligent Design: The Bridge Between Science E Theology (InterVarsity Press Academic).

Denton, Michael. 2016. Evolution: Still a Theory in Crisis (Discovery Institute Press).

\footnotetext{
${ }^{32}$ I would like to express my sincere thanks to two anonymous referees and to $F \mathcal{E} P$ 's editor, Mark Murphy, for their many helpful comments. The paper is certainly improved on account of their valuable input.
} 
Dougherty, Trent, and Ted Poston. 2008. "A User's Guide to Design Arguments." Religious Studies 44: 99-110. https://doi.org/10.1017/S003441250700933X

Dumsday, Travis. 2017. “Does a Delayed Origin for Biological Life Count as Evidence Against the Existence of God?" Sophia 56: 649-669. https://doi.org/10.1007/s11841-017-0574-0

Heathcote-James, Emma. 2002. Seeing Angels: True Contemporary Accounts of Hundreds of Angelic Experiences (John Blake).

John of Damascus. 1958. Writings. Translated by Frederic H. Chase Jr. (Catholic University of America Press).

Keck, David. 1998. Angels and Angelology in the Middle Ages (Oxford University Press).

Kelly, S. 1997. "The Problem of Evil and the Satan Hypothesis." Sophia 36: 29-42. https://doi.org/10.1007/BF02786068

Koperski, Jeffrey. 2015. The Physics of Theism: God, Physics, and the Philosophy of Science (Wiley-Blackwell). https://doi.org/10.1002/9781118933800

Lamoureux, Denis. 2016. Evolution: Scripture and Nature Say Yes! (Zondervan).

Lennox, John. 2009. God's Undertaker: Has Science Buried God? 2nd revised edition (Lion Hudson).

Leslie, John. 1989. Universes (Routledge).

Lewis, C. S. 1940. The Problem of Pain (Geofrey Bles).

Lewis, C. S. 1947. Miracles: A Preliminary Study (Geofrey Bles).

Lossky, Vladimir. 1957. The Mystical Theology of the Eastern Church. Translated by the Fellowship of St. Alban and St. Sergius (St. Vladimir's Seminary Press).

Mascall, Eric. 1956. Christian Theology and Natural Science: Some Questions on their Relations (Longmans, Green \& Co.).

McGrath, Alister. 2009. A Fine-Tuned Universe: The Quest for God in Science and Theology (Westminster John Knox Press).

Meyer, Stephen C. 2009. Signature in the Cell: DNA and the Evidence for Intelligent Design (HarperCollins).

Novotny, Vojtech. 2014. Cur Homo? A History of the Thesis Concerning Man as a Replacement for Fallen Angels. Translated by Paulina and Tim Morgan (Karolinum Press).

Pendergast, Richard. 2009. "Evil, Original Sin, and Evolution." Heythrop Journal 50: 833-845. https://doi.org/10.1111/j.1468-2265.2009.00472.x

Plantinga, Alvin. 1974. The Nature of Necessity (Oxford University Press).

Plantinga, Alvin. 1977. God, Freedom, and Evil (Eerdmans).

Ross, Hugh. 2008. Why the Universe Is the Way It Is (Baker Books).

Russell, Jeffrey Burton. 1981. Satan: The Early Christian Tradition (Cornell University Press).

Russell, Jeffrey Burton. 1984. Lucifer: The Devil in the Middle Ages (Cornell University Press).

Swinburne, Richard. 2004. The Existence of God, 2nd revised edition (Oxford University Press). https://doi.org/10.1093/acprof:oso/9780199271672.001.0001

Trethowan, Iltyd. 1954. An Essay in Christian Philosophy (Longmans, Green \& Co.). 
Webb, D. M. 1941. Why Does God Permit Evil? (P.J. Kennedy \& Sons).

Webb, Stephen H. 2010. The Dome of Eden: A New Solution to the Problem of Creation and Evolution (Cascade Books). 